\title{
A Preliminary Screening of the Different of Secondary Metabolites Ruku-Ruku Leaves (Ocimum tenuiflorum Linnen) in West Sumatera
}

\author{
Hesty Parbuntari*, Sri Benti Etika, Melindra Mulia, Elfanny Delvia
}

Chemistry Department, Faculty of Mathematics and Natural Science (FMIPA), Universitas Negeri Padang, Indonesia

*E-mail: hesty5193@fmipa.unp.ac.id

\begin{abstract}
Ruku-ruku leaves are used to remove distinctive odors from fish in some cuisine of West Sumatra. The characteristic odor comes from secondary metabolites especially essential oils. Therefore, secondary metabolites in ruku-ruku leaves have the potential to be further investigated as a source of bioactive compounds. The phytochemical screening of ruku-ruku leaves is a preminilary qualitative test that needs to be done to maximise its function as a medicinal plant. Based on the result data, there are some different result of flavonoid, steroids, and triterpenoids identification. Ruku-ruku leaves from Pesisir Selatan and Padang Panjang shows less flavonoid compounds tham Payakumbuh, Batusangkar, and Lubuk Alung. Both of this city and Payakumbuh also gives less steroids and triterpenoids. The factor influencing this result is caused by several factors, namely temperature, humidity, light exposure, and salinity.
\end{abstract}

Keyword: Ruku-Ruku, Preliminary Screening, Secondary Metabolites, Ocimum tenuiflorum Linnen, West Sumatera

\section{Introduction}

Indonesia with its natural products diversity has great potential to become a producer of medicinal plants [1][2]. Nevertheless, nowadays people use several types of plants as natural medicines based solely on personal experience. The community does not know the exact content of the medicinal plants. In fact, some plants that have the potential as medicines are only used as flavoring dishes such as the Ruku-ruku (Ocimum tenuiflorum Linnen).

Ruku-ruku is a wild plant and can be found on the roadside. Ruku-ruku has a morphology similar to basil (Ocimum sanctum). The part of this plant that is often used by the community is the leaves. Ruku-ruku leaves are often used in processed fish dishes in West Sumatra. This is caused by the distinctive odor of the leaves of ruku-ruku which can reduce the fishy smell of fish. The characteristic odor is predicted to originate from essential oils which are secondary metabolites as well as basil leaves. The secondary metabolites found in ruku-ruku leaves have the potential to be further investigated as a source of bioactive compounds, so the phytochemical screening of ruku-ruku leaves is a preminilary qualitative test that needs to be done to maximise its function as a medicinal plant. 
The difference in the content of essential oils which are secondary metabolites in ruku-ruku in several regions in West Sumatra can influence the use of these bioactive properties as medicinal compounds. The secondary metabolite compounds contained in plants are bioactive substances that are related to the chemical composition in plants [3]. Secondary metabolites are only found in specific organisms and only 4 are produced under certain conditions. The starting material (precursor) of biosynthetic secondary metabolites is obtained from the primary metabolic process. The structure and number of precursors determine the framework of the secondary metabolites that are formed. Although the structure of secondary metabolites is generally complex macromolecules, the number of precursors is very small in plants [3].

There are several factors that influence the quality content of plants. One of them is the quality of the soil or the growing environment of the plant. Soil chemistry which includes $\mathrm{pH}$, organic $\mathrm{C}$, CEC (Cation Exchange Capacity), and nutrient content can affect soil fertility [4]. The difference in nutrient content in the soil can affect the production of secondary metabolites [5]. In addition to soil factors, other environmental components that must also be considered are the altitude of the place. Some studies show that the relationship between land characteristics and crop quality also shows a real correlation, the quality of plants will be better if the soil is deeper in the effective depth of soil, rising soil $\mathrm{pH}, \mathrm{P}$-available, and CEC [6].

Phytochemical screening is one simple test that can be used to determine the content of secondary metabolites of a plant. The phytochemical screening results can be used for preliminary analysis of the potential of these plants to become drug compounds [7]. Therefore, in order to maximise the function of secondary metabolites in ruku-ruku in West Sumatra phytochemical screening should be carried out as a preliminary test.

\section{Experimental Section}

\subsection{Tools and Materials}

The tools used in this research were test tubes, Pasteur pipettes, mortar, pastle, pippete, volumetric flask, measuring cylinder, beaker glass, spatula, spraying bottle, filter paper, funnel, and distillation set. The materials were ruku-ruku leaves (Ocimum tenuiflorum Linnen), n-hexane, distillated water, sodium sulfate anhydrous, chloroform, ammonia, concentrated sulfuric acid, magnesium powder, cottons, acetic anhydride, concentrated hydrochloric acid, ethanol 70\%, aquadest, Wagner reagent, Dragendorff reagent, and Mayer reagent.

\subsection{Methods}

\subsubsection{Distillation and Extraction of Ruku-Ruku Leaves}

Ruku-ruku leaves were cut into small pieces and dried. Then, $15 \mathrm{~g}$ of dried ruku-ruku leaves were added about $50 \mathrm{~mL}$ of water and continued with distillation at $100^{\circ} \mathrm{C}$ for $4-5$ hours. The distillate is extracted with n-hexane three times and added sodium anhydrous to remove the remaining water. Essential oils are stored in a dark glass vial at $4{ }^{\circ} \mathrm{C}$ for further analysis.

\subsubsection{An Alkaloid Identification (Method of Culvenor-Fitzgeraid)}


0.5 grams of the extract was added by chloroform and ammonia-chloroform solution 0,05 $\mathrm{N}$. Then, the mixture was filtered and collected into a test tube. It was added by $5 \mathrm{~mL}$ of $\mathrm{H}_{2} \mathrm{SO}_{4} 2 \mathrm{~N}$ and strongly shaken. By waiting about 15 minutes, the mixture would be two layers. The layers should be separated. The upper layer was solution in $\mathrm{H}_{2} \mathrm{SO}_{4}$ and another one was solution solved in chloroform. The chlorofom solution was stored for terpenoid test. To a few $\mathrm{mL}$ of filtrate, some drops of two Mayer's reagent were added by the side of the test tube. A yellow precipitate indicated the test as positive. On the other hand, to few $\mathrm{mL}$ of filtrate, 1 or $2 \mathrm{~mL}$ of Wagner's reagent were added by the side of the test tube. A prominent brown or yellow precipitate indicated the test as positive. For the last test tube, to a few $\mathrm{mL}$ of filtrate, a drop or two drops of Dragendorff's reagent were added by the side of the test tube. A prominent orange or yellow precipitate indicated the test as positive.

\subsubsection{A Flavonoid Identification: Shinoda Test, Sianidin Test}

0,5 grams of ruku-ruku leaves were ground and extracted in $5 \mathrm{~mL}$ of methanol. The extract was then heated approximately 5 minutes through the test tube. The extract was added some drops of concentrated hydochloric acid and a few amount of magnesium powder. The colour changing into red or pink indicated the sample containing flavonoid.

\subsubsection{A Steroid/ Terpenoid Identification: Lieberman-Burchad Method}

A few drops of chloroform solution (the solution had been stored in Alkaloid identification) was dissolved in acetic anhydride. To this one or two drops of concentrated sulphuric acid were added slowly along the side of the test tube. An array of colour changes into orange or purple indicated the sample containing terpenoid while a blue colour change showed the positive result of steroid.

\subsubsection{Sapponins Identification}

To identify sapponin, the sample should be totally dried. The extract $0.5 \mathrm{~g}$ was added $70 \%$ of ethanol, stirred, and added $20 \mathrm{~mL}$ of aquadest. The suspension was shaken in a test tube for approximately 5 minutes. A foam forming for about 15 minutes indicated the presence of sapponins.

\section{Result and Discussion}

The function of secondary metabolites is different from primary metabolites. Each type of secondary metabolite has a different function. Secondary metabolites function as plant defense mechanisms, both from biotic and abiotic problems. Apart from being a defense mechanism, this compound also functions as an attractant. Certain secondary metabolites can be utilized by humans as antioxidants or medicinal raw materials [5]

Phytochemical screening is a simple way to prove the existence of secondary metabolites in plants. Phytochemical screening conducted in this study were to confirm the presence of compounds of alkaloids, flavonoids, steroids / terpenoids, and saponins. In this study, the existence of these groups of compounds can be known through qualitative tests on several reagents. Before the phytochemical screening is performed, the ruku-ruku leaves are distilled and extracted first to get n-hexane extract. The n-hexane extract will be 
evaporated and the remaining water may be removed by adding anhydrous sodium sulfate, so that the ruku-ruku leaf extract that is formed is more concentrated.

The precipitation in Mayer, Wagner and Dragendorff identification ensure the presence of alkaloid compounds. By adding Mayer reagent, alkaloid will produce complex of potassium-alkaloid (a yellow precipitate). This complex is produced when lone pair electrons of nitrogen atoms in alkaloid form covalent coordinate bonding with potassium from potassium tetraiodomercurate (II). Additionally, a brownish or yellowish precipitate also confirms the presence of alkaloid as a result of adding Wagner reagent to the extract. Similar to Mayer reagent, the precipitate proves the presence of potassium-alkaloid. Another method to identify alkaloid from the extract is Dragendorff. It will give a yellowish or brownish precipitate of potassaium-alkaloid complex [8][9] [10].

Flavonoid identification can be performed by adding magnesium powder and hydrochloric acid. It would produce a redish solution in reduction reaction . A redish solution represents flavium salt. While steroid or terpenoid identification can be performed when adding concentrated $\mathrm{H}_{2} \mathrm{SO}_{4}$ in acetic acid anhydride as solvent. It will give red orange or purple for terpenoids and blue for steroids. Furthermore, a reddish colour change would identify the presence triterpenoid [11].

On the other hand, sapponin identification was performed by shaking a chopped ruku-ruku leave in aquadest. The presence of glycosides could produce foam in water hydrolised in glucose and other compounds [11]. Miscellanea would be produced when the ruku-ruku leaves are shaked strongly with water. In the miscellanea, polar group of glycosyl face the outside and nonpllar group of steroids or triterpenoids face the inside. Therefore, the foam is produced.

Secondary metabolites present in plants are produced from biosynthesis of primary metabolites present in these plants such as carbohydrates, lipids, and amino acids [12]. For example, both the pentose phosphate pathway as the Calvin cycle prepare carbonic skeletons for the erythrose-4-phosphate, which form shikimate through some reactions, in order to produce phenylalanine, which is the precursor for the phenylpropanoid metabolism Although each group or type of secondary metabolites will undergo the same synthesis pathway, the content of secondary metabolites in a plant type can have a different composition or type of secondary metabolite group.

Table 1. Result of Phytochemical Screening of Ruku-Ruku Leaves in Sumatera Barat

\begin{tabular}{|c|c|c|c|c|c|}
\hline \multirow{2}{*}{$\begin{array}{c}\text { Secondary } \\
\text { Metabolites }\end{array}$} & \multicolumn{5}{|c|}{ Sources of Ruku-ruku leaves } \\
\hline & $\begin{array}{c}\text { Payakumbu } \\
\mathrm{h}\end{array}$ & Batusangkar & $\begin{array}{c}\text { Lubuk } \\
\text { Alung } \\
\text { (Pariaman } \\
\text { ) }\end{array}$ & $\begin{array}{l}\text { Padang } \\
\text { Panjang }\end{array}$ & $\begin{array}{c}\text { South } \\
\text { Pesisir } \\
\text { (Painan } \\
\text { ) }\end{array}$ \\
\hline \multicolumn{6}{|l|}{ Alkaloid } \\
\hline - Mayer & +++ & +++ & +++ & +++ & ++ \\
\hline - Wagner & +++ & +++ & +++ & +++ & +++ \\
\hline - Dragendorff & +++ & +++ & +++ & +++ & +++ \\
\hline
\end{tabular}




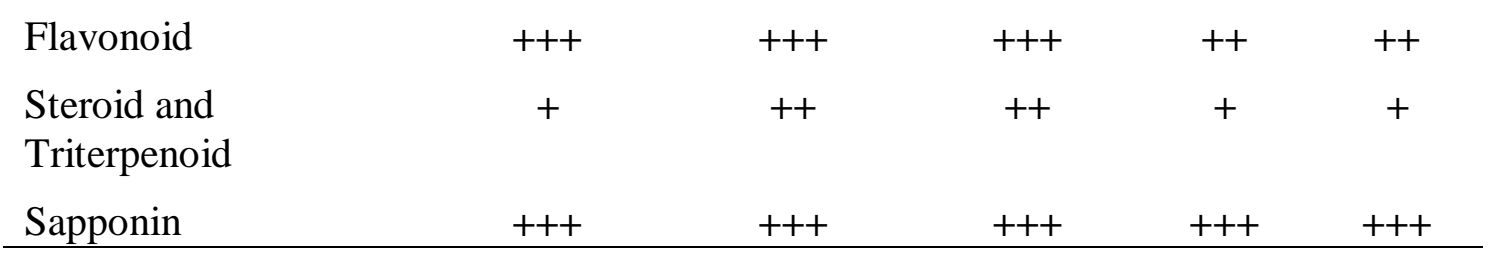

Macronutrients of soil such as Nitrogen (N), Potassium (K), Organic Materials (BO) and Organic Carbon (C) have a linear relationship with the formation of secondary metabolites. The content of secondary metabolites that were detected based on the results of phytochemical screening on n-hexane extract of ruku-ruku leaves were alkaloids, flavonoids, steroids, terpenoids, and saponins. Based on the results of phytochemical screening, it can be seen that there are differences in the content of secondary metabolites in ruku-ruku leaf extracts in Payakumbuh, Batusangkar, Padang Panjang, South Pesisir, and Lubuk Alung (Table 1). The sample selection in this study was carried out by cluster random sampling.

Based on the results of this study, the most visible difference is in the identification of flavonoids and steroids or terpenoids. Humidity level, rainfall, temperature, water availability and solar radiation will influence the changing of secondary metabolites of leaves and stems [15]. The availability of certain macronutrients $(\mathrm{Ca}, \mathrm{Mg}, \mathrm{P}$, and $\mathrm{K})$ and micronutrients $\mathrm{Cu}$ significantly affecting the metabolic profile in the root and inflorescenes. Other factor such as climate (high temperature, drought, wide thermal amplitude, freezing, or high levels of solar radiation) will give the production of secondary metabolites as well [15][16][17][18][19]. It means that under stress condition, plants may shows changes in the production of various secondary metabolites.

Under stress conditions, enzyme activity which is one of the important things in the synthesis of secondary metabolites can be increased. Enzyme activities that are quite affected in these conditions are phenylalanine ammonia lyase (PAL) and chalcone synthase (CHS) [20]. On the other hand, PAL and CHS are the main enzymes in flavonoid biosynthesis, so that if the enzyme activity decreases or increases, flavonoid production will also be affected. PAL is the main enzyme that functions in defense by producing phenol and lignin compounds. It is also the first enzyme in the phenylpropanoids pathway and one of the enzymes involved in the synthesis of polyphenols, a catalyst in the deamination of L-phenylalanine to produce cinnamic trans-acids, or as an intermediary in the biosynthesis of phenol compounds [21].

Salinity of plants that contain potential as a medicinal plant can affect the content of secondary metabolites as well, for example high salt levels can cause the production of more terpene compounds. These compounds are usually in the form of essential oils. Terpenoids are a major component of essential oils. However, we can also find phenylpropanoid compounds in essential oils. The terpenoid was synthesized with five carbon units from isopentenyl pyrophosphate (IPP) and its isomer, dimethylallyl pyrophosphate (DMAPP). When prenyl pyrophosphate synthase binds to IPP and DMAPP, the monoterpenoid-monoterpenoid (C-10) and sesquiterpenoid-sesquiterpenoid (C-15) groups will be produced [21].

Based on the results of this study (Table 1), identification of flavonoids in Padang Panjang and South Pesisir shows results that are not very clear. This shows that the 
concentration of flavonoid compounds in ruku-ruku leaves in Padang Panjang and South Pesisir is lower than the other three regions (Payakumbuh, Batusangkar, and Lubuk Alung). Several factors that influence the decrease in the concentration of flavonoids in the two regions are the photoperiod and salinity effects. Based on climate and weather reports from the Meteorological, Climatology and Geophysics Agency (BMKG) website, Kota Panjang has the least amount of sun exposure with a higher humidity level than the other four cities.

Table 2. Report of Weather based on website BMKG

\begin{tabular}{cccc}
\hline City & Weather & Temperature $\left({ }^{\circ} \mathrm{C}\right)$ & Humidity $(\%)$ \\
\hline Payakumbuh & $\begin{array}{c}\text { Cloudy to } \\
\text { sunny }\end{array}$ & $18-27$ & $65-95$ \\
Batusangkar & Sunny & $21-26$ & $70-95$ \\
$\begin{array}{c}\text { Lubuk Alung } \\
\text { (Pariaman) }\end{array}$ & Cloudy & $24-30$ & $75-95$ \\
$\begin{array}{c}\text { Padang Panjang } \\
\text { Cloudy to } \\
\text { Rainy }\end{array}$ & $19-23$ & $80-100$ \\
$\begin{array}{c}\text { South Pesisir } \\
\text { (Painan) }\end{array}$ & Cloudy & $22-30$ & $75-95$ \\
\hline
\end{tabular}

Plant growth and development is influenced by the duration of light exposure which is directly related to the biosynthesis of secondary metabolites [22][23]. Previous research concluded that the duration of solar radiation plays an important role in regulating the levels of various phenolic phenylpropane derivatives in the Xanthium species. When compared with plants that are exposed to sunlight for a longer time, shorter duration of light exposure can reduce some flavonoid compounds or even achieve twice the reduction as in aglycones flavonoids [24]. In the short duration of light exposure, the content of anthocyanins in Pinus contorta is lower compared to its composition in areas exposed to more sunlight [25]

Factors influencing the decrease in flavonoid concentrations in ruku-ruku leaves in South Pesisir are different from those in ruku-ruku leaves in Padang Panjang because the level of sunlight exposure in South Coast tends to be normal with other cities. However, when compared to its geographical location, South Coast is located by the coast or the sea so that the salinity in the area is higher than the other four cities. However, the composition of phenol compounds in plants against salinity stress depends on the type of plant. Salinity stress can reduce levels of phenol compounds (chlorogenic and synapatic acid derivatives and flavonoids) in broccoli (B. oleracea var. Italic cv. Marathon) and the decrease is higher for flavonoids than synapatic acid derivatives [26]

\section{Conclusion}

Phytochemical tests of ruku-ruku leaves in Payakumbuh, Batusangkar, Lubuk Alung, Padang Panjang, and South Pesisir showed several differences such as the results of identification of flavonoids and steroids or terpenoids. The difference in identification results is caused by several factors, namely temperature, humidity, light exposure, and salinity. 


\section{References}

[1] A. Crozier, I. B. Jaganath, and M. N. Clifford, "Phenols, Polyphenols and Tannins: An Overview," Plant Second. Metab. Occur. Struct. Role Hum. Diet, no. i, pp. 1-24, 2007.

[2] A. O. Taylor, " Some Effects of Photoperiod on the Biosynthesis of Phenylpropane Derivatives in Xanthium," Plant Physiol., vol. 40, no. 2, pp. 273-280, 1965.

[3] B. Hérault et al., "Functional traits shape ontogenetic growth trajectories of rain forest tree species," J. Ecol., vol. 99, no. 6, pp. 1431-1440, 2011.

[4] B. L. Sampaio, R. Edrada-Ebel, and F. B. Da Costa, "Effect of the environment on the secondary metabolic profile of Tithonia diversifolia: A model for environmental metabolomics of plants," Sci. Rep., vol. 6, no. July, pp. 1-11, 2016.

[5] B. Yang, J. Zheng, O. Laaksonen, R. Tahvonen, and H. Kallio, "Effects of latitude and weather conditions on phenolic compounds in currant (Ribes spp.) cultivars," $J$. Agric. Food Chem., vol. 61, no. 14, pp. 3517-3532, 2013.

[6] C. López-Berenguer, M. D. C. Martínez-Ballesta, D. A. Moreno, M. Carvajal, and C. García-Viguera, "Growing hardier crops for better health: Salinity tolerance and the nutritional value of broccoli," J. Agric. Food Chem., vol. 57, no. 2, pp. 572-578, 2009

[7] "Cold-induced purpling of Pinus contorta seedlings depends on previous daylength treatment," Plant. Cell Environ., vol. 16, no. 6, pp. 761-764, 1993.

[8] C. V. Borges, I. O. Minatel, H. A. Gomez-Gomez, and G. P. P. Lima, "Medicinal plants: Influence of environmental factors on the content of secondary metabolites," Med. Plants Environ. Challenges, pp. 259-277, 2017.

[9] F. Synthesis, "Detection and Identification of Organic Compounds in Wastewater of Final Effluent Treatment Plant by FTIR and GC-MS," J. Adv. Chem. Sci., vol. 2, no. 2, pp. 223-226, 2016.

[10] G. Svehla, Vogel - Text book of macro and semimicro qualitative inorganic analysis 5ed.pdf, Fifth edit. New York: Longman Group Limited, 1990.

[11] H. B. Jakobsen and C. E. Olsen, "Clockforll Ih / I," Planta, pp. 365-371, 1994.

[12] H. Parbuntari, Y. Prestica, R. Gunawan, M. N. Nurman, and F. Adella, "Preliminary Phytochemical Screening (Qualitative Analysis) of Cacao Leaves (Theobroma cacao L.)," EKSAKTA Berk. Ilm. Bid. MIPA, vol. 19, no. 2, pp. 40-45, 2018.

[13] I. Anita Sari and A. Wahyu Susilo, "Keberhasilan sambungan pada beberapa jenis batang atas dan famili batang bawah kakao (Theobroma cocoa L.). (Grafting performance of some scion clones and root-stock family on cocoa (Theobroma cocoa L.)," Pelita Perkeb. (a Coffee Cocoa Res. Journal), vol. 28, no. 2, pp. 72-81, 2012.

[14] J. E. Mcmurry et al., Chemistry seventh edition, Seventh ed. New York: Pearson Education, 2014.

[15] L. Jaakola and A. Hohtola, "Effect of latitude on flavonoid biosynthesis in plants," Plant, Cell Environ., vol. 33, no. 8, pp. 1239-1247, 2010.

[16] M. H. Ibrahim, H. Z. E. Jaafar, E. Karimi, and A. Ghasemzadeh, "Primary, secondary metabolites, photosynthetic capacity and antioxidant activity of the Malaysian Herb Kacip Fatimah (Labisia pumila Benth) exposed to potassium fertilization under greenhouse conditions," Int. J. Mol. Sci., vol. 13, no. 11, pp. 15321-15342, 2012.

[17] M. K. Meiske S. S., Lidya I. M., "Uji Toksisitas dan Skrining Fitokimia Tepung Gabah Pelepah Aren (Arenga pinnata)," vol. 12, no. 2, pp. 127-134, 2012.

[18] M. Salim, Y. Yahya, H. Sitorus, T. Ni'mah, and M. Marini, "Hubungan Kandungan 
Hara Tanah dengan Produksi Senyawa Metabolit Sekunder pada Tanaman Duku (Lansium domesticum Corr var Duku) dan Potensinya sebagai Larvasida," J. Vektor Penyakit, vol. 10, no. 1, pp. 11-18, 2017.

[19] N. Noorhidayah, "Potensi Dan Keanekaragaman Tumbuhan Obat Di Hutan Kalimantan Dan Upaya Konservasinya," J. Anal. Kebijak. Kehutan., vol. 3, no. 2, pp. 95-107, 2017.

[20] R. A. Dixon et al., "Phenolic Metabolism in Plants," in Phenolis Metabolism in Plants, H. A. S. and R. K. IBRAHIM, Ed. New York, 1992, pp. 91-92.

[21] S. Caretto, V. Linsalata, G. Colella, G. Mita, and V. Lattanzio, "Carbon fluxes between primary metabolism and phenolic pathway in plant tissues under stress," Int. J. Mol. Sci., vol. 16, no. 11, pp. 26378-26394, 2015.

[22] T. Nofelman, A. Karim, and A. Anhar, "Analisis Kesesuain Lahan di Kabupaten Simeulue," Manaj. Sumberd. Lahan, vol. 1, no. 1, pp. 62-71, 2012.

[23] T. O. Low, D. Graham, and B. D. Patterson, "Responses of Plants," Annu. Rev. Plant Physiol., vol. 33, pp. 347-372, 1982.

[24] V. Arbona, M. Manzi, C. de Ollas, and A. Gómez-Cadenas, "Metabolomics as a tool to investigate abiotic stress tolerance in plants," Int. J. Mol. Sci., vol. 14, no. 3, pp. 4885-4911, 2013.

[25] V. Lattanzio et al., "Relationship of secondary metabolism to growth in oregano (Origanum vulgare L.) shoot cultures under nutritional stress," Environ. Exp. Bot., vol. 65 , no. 1 , pp. 54-62, 2009.

[26] V. Shulaev, D. Cortes, G. Miller, and R. Mittler, "Metabolomics for plant stress response," Physiol. Plant., vol. 132, no. 2, pp. 199-208, 2008. 